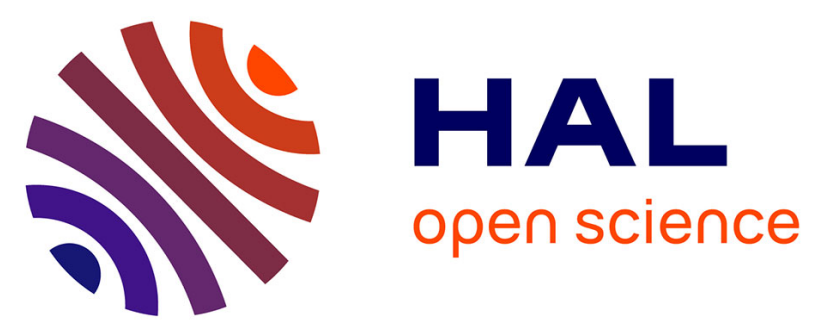

\title{
Micro-tectonic constraints on the evolution of the Barles half-window (Digne Nappe, southern Alps). Implications for the timing of folding in the Valensole foreland basin
} Marc Fournier, Philippe Agard, Carole Petit

\section{- To cite this version: \\ Marc Fournier, Philippe Agard, Carole Petit. Micro-tectonic constraints on the evolution of the Barles half-window (Digne Nappe, southern Alps). Implications for the timing of folding in the Valensole foreland basin. Bulletin de la Société Géologique de France, 2008, 179, pp.551-568. hal-00581751}

\section{HAL Id: hal-00581751 \\ https://hal.sorbonne-universite.fr/hal-00581751}

Submitted on 31 Mar 2011

HAL is a multi-disciplinary open access archive for the deposit and dissemination of scientific research documents, whether they are published or not. The documents may come from teaching and research institutions in France or abroad, or from public or private research centers.
L'archive ouverte pluridisciplinaire HAL, est destinée au dépôt et à la diffusion de documents scientifiques de niveau recherche, publiés ou non, émanant des établissements d'enseignement et de recherche français ou étrangers, des laboratoires publics ou privés. 
Micro-tectonic constraints on the evolution of the Barles half-window (Digne Nappe, southern Alps). Implications for the timing of folding in the Valensole foreland basin Marc Fournier $^{1,2^{*}}$, Philippe Agard ${ }^{1}$, Carole Petit $^{1}$

${ }^{1}$ Laboratoire de Tectonique, Université Pierre et Marie Curie-Paris6, CNRS UMR 7072, UCP, Case 129, 4 place Jussieu, 75252 Paris, France

${ }^{2}$ Laboratoire de Géologie, Ecole Normale Supérieure, CNRS UMR 8538, 24 rue Lhomond, 75005 Paris, France

* Corresponding author: marc.fournier@upmc.fr 
Keywords: Barles tectonic half-window, Digne Nappe, Valensole foreland basin, external western Alps, stress-field evolution, growth fold

Abstract. The "Vélodrome" overturned syncline, at the northern margin of the Cenozoic foreland basin of Valensole in SE France, was formed during the Late Cenozoic at the front of the Digne Nappe. Microstructural analyses reveal that mesoscale faulting in the molassic series, from the Oligocene "Molasse Rouge" at the base to the middle to late Miocene "Valensole Conglomerates" at the top, partly occurred before the folding, as layer-parallel shortening: the NNE-SSW-directed compression is recorded by two systems of reverse and strike-slip faults, which formed when the strata were still horizontal and were passively tilted as folding occurred. These data suggest that the Vélodrome folding postdates the deposition of the Valensole Conglomerates and occurred in late Miocene-Pliocene times during the emplacement of the Digne Nappe. These results are difficult to reconcile with the interpretation of the Vélodrome as a growth fold progressively formed in 10-15 m.y. during the deposition of the Miocene molasses. Structural data collected in the Barles tectonic halfwindow enable to reconstruct the evolution of the deformation since the Jurassic. The two main phases of shortening, the pre-Oligocene Pyrenean-Provençal and the Mio-Pliocene Alpine phases, are almost homoaxial with a direction of compression trending N-S for the former and NNE-SSW for the later. A late Eocene-basal Oligocene N-S extensional episode is documented between these two phases, probably in relation with the formation of the Western European rift system. The direction of extension of the Liassic rifting of the Alpine Tethys is roughly constrained in the NW-SE quadrant. Paleo-stress field reconstruction brings consistent results at the regional scale and proves to be a powerful tool to decipher the evolution of the deformation in a remarkably complicated tectonic setting. 


\section{Contraintes microtectoniques sur l'évolution de la demi-fenêtre de Barles (Nappe de}

Digne, Alpes du Sud). Implications pour l'âge du plissement dans le bassin d'avant-pays

\section{de Valensole}

Mots clés : demi-fenêtre de Barles, Nappe de Digne, bassin d'avant-pays de Valensole, évolution du champ de contraintes, Alpes externes, pli de croissance

Résumé. Le pli couché du "Vélodrome" s'est formé à la fin du Tertiaire au front de la nappe de Digne, sur la bordure nord du bassin molassique d'avant-pays de Valensole dans le sud-est de la France. L'analyse micro-structurale montre que la fracturation à petite échelle s'est produite dans la série molassique, depuis la "Molasse Rouge" Oligocène à la base jusqu'aux Conglomérats de Valensole d'âge Miocène moyen à supérieur au sommet, en partie avant le plissement, en accommodant du raccourcissement parallèle aux couches : la compression NNE-SSW est enregistrée par deux systèmes de failles inverses et décrochantes, qui se sont formés quand les couches étaient encore horizontales et qui ont été basculés passivement pendant le plissement. Ces données suggèrent que le plissement du Vélodrome est postérieur au dépôt des Conglomérats de Valensole et s'est produit au Miocène supérieur-Pliocène pendant la mise en place de la Nappe de Digne. Ces résultats sont en contradiction avec l'interprétation du Vélodrome comme un pli de croissance formé progressivement en 10-15 millions d'années pendant le dépôt des molasses miocènes. Les données structurales collectées dans la demi-fenêtre de Barles permettent de reconstruire l'évolution de la déformation depuis le Jurassique. Les deux principales phases de raccourcissement, la phase pyrénéo-provençale anté-Oligocène et la phase alpine Mio-Pliocène, sont pratiquement homoaxiales avec une direction de compression orientée N-S pour la première et NNE-SSW pour la seconde. Un épisode extensif N-S d'âge Eocène supérieur à Oligocène basal s'est intercalé entre ces deux phases, probablement en relation avec la formation du système de rift ouest- 
européen à cette époque. La direction d'extension associée au rifting Liasique de la Téthys alpine est grossièrement contrainte dans le quadrant NW-SE. La reconstruction du paléochamp de contraintes dans un contexte tectonique particulièrement complexe, caractérisé par des déformations superposées et un intense cisaillement simple lié à la mise en place de la nappe de Digne, apporte des résultats cohérents à l'échelle régionale et s'avère être un outil puissant pour déchiffrer l'évolution de la déformation. 


\section{Introduction}

The front of the Alpine belt is famous in the area of Barles, SE France, for its spectacular and well-exposed sedimentary and tectonic evolution characterized by superimposed deformations and the emplacement of the Digne Nappe [fig. 1; Haug, 1891; de Lapparent, 1938; Gubler, 1959; Goguel, 1963; Debelmas and Lemoine, 1970; Beaudoin and Gigot, 1971; Debelmas, 1974; Clauzon, 1975; Siddans, 1979; Debelmas and Kerckhove, 1980; Tricart, 1984; Gidon and Pairis, 1992; Ford et al., 1999].

In this area of the Alpine foreland, the evolution of the deformation is well constrained. Following the emplacement of the internally-derived Embrunais-Ubaye nappes in early Oligocene times [Kerckhove, 1969; Merle and Brun, 1984; Tricart, 1986], collision developed and progressively migrated westward in the external zone [Tricart, 1984; Sinclair and Allen, 1992; Ford et al., 2006]. The Penninic Frontal thrust formed at c. 25 Ma [Tricart et al., 2001], the Digne Nappe was emplaced during the Mio-Pliocene [Lemoine, 1973; Gidon \& Pairis, 1992], and deformation reached the continental Valensole Conglomerates of the Durance valley during the Quaternary [Jorda et al., 1992; Hippolyte and Dumont, 2000]. At present, only minor shortening is occurring in the external Alps [Jouanne et al., 2001; Calais et al., 2001, 2002], while extension, which started c. 20-15 Ma ago in the internal Alps [Tricart et al., 2001; Agard et al. 2003], is still active at the rear of the belt [Sue et al., 1999].

The Digne Nappe, made of up to 5000 m thick Liassic to Eocene deposits [Gidon, 1975], is the prominent tectonic feature in this part of the external zone. Thickness variations of the Liassic and Dogger deposits between the nappe (up to $2000 \mathrm{~m}$ thick) and the autochtonous ( 200 $\mathrm{m}$ in the area of Barles; Gubler et al., 1961; Mouterde, 1961; Mouterde et al., 1971) suggest that they formed within an Early to Middle Jurassic extensional basin of the Tethyan margin inverted during Alpine compression [Arnaud et al., 1977; Lemoine et al., 1986; Gidon and Pairis, 1986; Fry, 1989]. Based on the sequential restoration of a balanced section across the Southern Subalpine Chains, Lickorish and Ford [1998] showed that the Digne Nappe 
travelled for about $10 \mathrm{~km}$ towards the SW [Faucher et al., 1988; Aubourg et al., 1999] during the late Miocene [Gidon and Pairis, 1988]. Its latest movement was attributed to the Late Pliocene [de Lapparent, 1938; Clauzon, 1975; Dubar, 1984], to the Pleistocene [Jorda et al., 1992] or even to the late Quaternary [Hippolyte and Dumont, 2000]. Several studies suggest that deformation affected the foreland basin in the area of Barles over a larger time span, approximately since the Early Miocene, allowing for the development of syn-tectonic sedimentary patterns such as the Vélodrome overturned syncline at the northern margin of the Digne-Valensole basin [Gigot et al., 1974; Haccard et al., 1989b; Crumeyrolle et al., 1991; Gidon and Pairis, 1992]. Besides, subsurface data in the vicinity of the Durance fault in the western part of the Valensole basin document a late folding of the molasse formations between the Late Miocene and the present [Roure and Coletta, 1996].

In order to better assess the tectonic evolution of the area and the continuity of deformation patterns, we conducted a microtectonic survey of the Barles area. Despite regional studies of the present and past stress fields [e.g., Bergerat, 1987; Labaume et al., 1989; Ritz, 1992; Rebai et al., 1992; Madeddu et al., 1996; Baroux et al., 2001] pointing to the influence of the Alpine collision to the east and the opening of the Gulf of Lion to the south, no detailed study exists so far in the Barles area. We will show that the main stages of the tectonic evolution of SE France are well recorded in the area and that folding in the foreland basin occurred mainly after the deposition of the Valensole Conglomerates.

\section{Tectono-stratigraphic setting of the sedimentary units}

\subsection{Key sedimentary patterns and evolution of depositional environments}

The stratigraphic succession of the Barles tectonic half-window includes Triassic to upper Miocene formations (fig. 2). The Triassic series resting unconformably upon the Hercynian basement (exposed in the Clue de Verdaches, north of Barles) are made of evaporites and dolomites, which testify to very shallow depositional environments. The overlying Liassic 
formations are dominated by open marine, carbonate platform deposits. They display important lateral facies variations reflecting synsedimentary extensional deformation [Haccard et al., 1989b], particularly in the Domerian levels [Coadou et al., 1971]. The Dogger turbiditic deposits (with Cancellophycus or Zoophycos) and black shales ("Terres Noires") indicate a deep marine sedimentation coeval with increased subsidence. The Malm is characterized by a thick carbonate sequence with evidences of syn-sedimentary re-working (slumps and breccia), indicative of an external platform environment. During the early Cretaceous, carbonate platform sedimentation prevailed, with tectonic instabilities (slumps) and increased subsidence [Haccard et al., 1989b].

A major hiatus occurs in the Barles area from the late Early Cretaceous (Aptian-Albian) to the late Eocene. Cenozoic molassic deposits are unconformably overlying the previously folded and eroded Mesozoic formations. The fluvial red-clay deposits of the continental Molasse Rouge Formation of Oligocene age are onlapping on the eroded Mesozoic rocks. The Molasse Rouge Formation is in places underlain by a basal breccia of presumably late Eocene to basal Oligocene age [Haccard et al., 1989b]. The end of the Oligocene is marked by the transition from continental to lacustrine and finally shallow-marine sedimentation, which then prevailed throughout the lower Miocene. Three members are distinguished in the marine molasse succession: conglomeratic molasses [Aquitanian-Burdigalian; Gigot and Mein, 1973] with bird footprints at the base [Beaudoin and Gigot, 1971; Couëffé et al., 2004] are overlain by silty and marly molasses of Burdigalian age [Couëffé and Maridet, 2003], capped at the top by a molasse with Cerithes (Langhian-early Serravalian; Beaudoin et al., 1966). Analysis of the depositional sequences of the marine molasse succession showed that the sequences correlate to the early and middle Miocene global eustatic events [Crumeyrolle et al., 1991; Sissingh, 2001].

The youngest formations correspond to coarse continental clastic deposits. The Valensole Conglomerates consists of terrigeneous alluvial fan deposits with conglomerates and 
sandstones of middle to late Miocene age. Their age is diachronous and starts in the early Serravalian ( 14 Ma) in the area of Barles and Tortonian ( $\sim 9 \mathrm{Ma})$ further to the south [Clauzon et al., 1987, 1989]. Most of the Valensole basin infill predates the Messinian dessication event of the Mediterranean (i.e., it is older than $6 \mathrm{Ma}$ ), except for the Pliocene filling of Messinian canyons to the south [Clauzon, 1979; Dubar, 1984]. Upwards and laterally, the Valensole Conglomerates Formation gradually passes to the Tanaron Formation characterized by abundant hectometre-sized olistoliths.

Stratigraphic and sedimentary patterns therefore show that:

(1) subsidence in Liassic times, attributed to the rifting of the Alpine Tethys [Lemoine and De Graciansky, 1988], followed a prerift period dominated by evaporitic deposits and strongly increased in the late Jurassic and early Cretaceous in relation with the formation of the Vocontian Trough [Curnelle and Dubois, 1986];

(2) a first deformation phase causing emersion, folding and erosion took place between the late Cretaceous and late Eocene times;

(3) molasse deposits accumulated above a major basal unconformity in the foreland Valensole basin at the front of the alpine nappes from the Oligocene until the end of the Miocene. The asymmetric infill of the basin, thickest to the east than to the west [Crumeyrole et al., 1991], reflects a regional load-induced flexural subsidence.

\subsection{Outline of the main tectonic features}

The whole region is structured by E-W trending folds, which have been strongly eroded before the Priabonian [fig. 1c; Lemoine, 1972]. These folds are related to the PyreneanProvençal deformation phase, or possibly to the pre-Senonian phase of folding of the Dévoluy [Flandrin, 1966]. In the Barles region, unfolding of the Oligocene unconformity indicates that these folds were asymmetric with a vertical southern limb and a northward gently dipping northern limb. A second stage of folding is recorded in the Oligo-Miocene foreland basin 
deposits, which are affected by $\sim \mathrm{E}-\mathrm{W}$-trending, south- to southwest-verging folds. These folds are characterized by an E-W trending, northward-dipping, schistosity that is found in every stratigraphic level of the molassic sequence including the Valensole Conglomerates.

Between these two stages of folding, an extensional deformation stage also affected the area, as recorded by km-sized E-W striking faults dipping north, reworking axial planes of earlier E-W trending folds, and concealed by the Oligocene Molasse Rouge [fig. 1b; Haccard et al., 1989a]. Finally, the gentle doming of the area and subsequent erosion are responsible for the exposure of the Barles half-window [Gigot et al., 1974].

\section{Neogene deformation in the foreland basin and the Mesozoic series}

About 950 microtectonic measurements, including striated fault planes, tectonic joints, and bedding planes, have been carried out in the Barles tectonic half-window, in both the foreland basin and the Mesozoic series (Tables 1 and 2). The orientation of the principal stress axes was determined from inversion of fault-slip data using computer-aided methods developed by Angelier [1984, 1990]. If necessary, i.e. when fault-slip data sets were too complex to be interpreted with a single stress tensor because of a mechanical incompatibility between fault slips and readily resulted from superimposed tectonic events, homogeneous fault subsets were separated and labelled with A or B suffix. Sorting was done in two ways: (1) at sites where all fault planes are of the same type (e.g., strike-slip faults), they were sorted according to strike (e.g., site M1A and M1B); (2) at sites where two different types of fractures are observed (e.g., normal and strike-slip faults), the two subsets were distinguished (e.g., site L2A and L2B).

Moreover, in folded areas, it is necessary to determine the timing of faulting relative to folding and resulting bed tilting (Yamaji et al., 2005). Faults may have formed before, during, or after folding. Following Anderson (1951), we assume that away from major fault zones, one of the three principal stress axes of a tensor is generally vertical (e.g., Fabbri, 2000 ; 
Vandycke and Bergerat, 2001 ; Lacombe et al., 2006). Whenever a fault set forms before folding and is secondarily tilted with the bedding, the tensor calculated on this set does not display a vertical axis, yet one of the stress axes is found perpendicular to bedding (the two others lying within the bedding plane). In such a case, the fault system can be interpreted after back tilting to its initial position, i.e., correction from the tilt of the strata (horizontal rotation axis parallel to bedding strike, and rotation angle corresponding to bedding dip), as was done in the present study. In the complicated case of several stages of post-faulting folding that correspond to several stages of rotation around different axes, a single back-tilting should not restore the fault system to its initial position. However, if the fault systems indicate homogenous stress directions at regional scale after a single back-tilting, this attests that the successive rotations were nearly homo-axial. One can then assume that the fault systems are roughly restored to their initial position. If the fault activity occurred during folding, it is necessary to determine to what amount the beds were rotated when the faults were activated. This can be achieved by a partial back tilting of the whole system (faults, stress tensor, and bedding) until recovering a vertical stress axis. This geometrical reasoning allows separation of fault subsets based on their age relative to fold development.

\subsection{Record of pre-folding, layer-parallel NNE-SSW shortening in the molasse}

\section{succession}

Several sets of conjugate faults, at first glance somewhat scattered in orientation, are found in all the molasse formations of the foreland basin, from the basal breccia of the Molasse Rouge to the Valensole Conglomerates (fig. 3). These can be sorted into two ubiquitous subsets: (1) faults lying at low angle (from $15^{\circ}$ to $40^{\circ}$ ) with respect to the bedding plane (e.g., sites T4A and T33A), and (2) faults with slickensides consistently lying within the bedding plane whatever the strata orientation and the dip (e.g., sites T4B and T33B). The determination of the principal stress axes from these fault sets always provide one of the 
stress axes perpendicular to bedding. After back-tilting of the strata, two coherent fault systems appear, respectively represented by (1) stereodiagrams with a vertical $\sigma_{3}$, corresponding to conjugate reverse faults, and (2) stereodiagrams with a vertical $\sigma_{2}$, corresponding to conjugate strike-slip faults (fig. 3 and fig. 4). The two subsets advocate for a similar direction of compression $\left(\sigma_{1}\right)$ striking between N-S and NE-SW. Relative chronology criteria are seldom observed. In one outcrop only (site T4), cross-cutting relationships suggest that strike-slip faulting postdated reverse faulting. The existence of these two, subsequently tilted, reverse and strike-slip fault systems indicates that faulting occurred prior to the onset of folding of the molasse series and accommodated layer-parallel shortening.

\subsection{Record of post-folding NNE-SSW compression}

The same NNE-SSW direction of compression is documented by conjugate fault populations affecting the whole Triassic to Miocene sequence of the Barles tectonic halfwindow (fig. 5). In contrast with the previous fault subsets, however, these display two main direction of stress horizontal suggesting they have been formed after folding. Strike-slip faulting clearly prevails. The right-lateral faults generally strike N-S and the left-lateral faults strike $\mathrm{N} 60^{\circ} \mathrm{E}$. In places however, especially in the Clue de Barles and Clue du Pérouré where strata are steeply dipping or vertical, left-lateral strike-slip faulting preferentially reactivated favourably oriented E-W bedding planes (sites K1B and M1B). All these observations show that the NNE-SSW compression persisted after folding over the whole area.

\subsection{Record of syn-folding NNE-SSW compression}

One example of syn-folding faulting was observed in the conglomeratic molasse in site T31 (fig. 6, location in fig. 7). The partial back-tilting of the stereodiagram yields a system of conjugate reverse faults $\left(\mathrm{T} 31^{* *}\right)$ with $\sigma_{1}$ striking $\mathrm{N} 030^{\circ} \mathrm{E}$, i.e., similar to those reported above, whereas an inconsistent stress solution (marked by sub-vertical faults with high 
pitches) is found after a complete back-tilting. It is therefore likely that the very same compressional event, which predated folding, also prevailed during and after folding. This results agrees with the existence of numerous tens to hundreds of metres wavelength folds with axes trending $\mathrm{N} 120^{\circ} \mathrm{E}$ on average, found in all units of the Barles half-window (fig. 7), which indicate a NNE-SSW direction of shortening.

However, it is worth noting that site 31 is located at the N-S closure of the Vélodrome fold to the east, at Esclangon. This closure could result from two successive deformation stages, as advocated by Gidon and Pairis (1992). Successive tilting of strata of site 31 during these two stages could explain why only partial tilting is required to retrieve an Andersonian stress tensor.

One conclusion of this survey of brittle deformation in the molasse succession is that small-scale faulting occurs mainly before folding and after fold development, as already reported in other regions [e.g. Lacombe et al., 2006]. The limited evidence of syn-folding faulting suggests that brittle faulting of strata is mainly achieved during two specific stress loading stages which seem to predate immediately folding (buckling) and to prevail after fold tightening [Onasch, 1983].

\section{Pre-Oligocene deformation in the Barles tectonic half-window}

\subsection{Late Eocene extension stage}

A N-S-directed extension is documented by E-W trending conjugate normal faults displaying mostly dip-slip striations in the Mesozoic formations and in the late Eocene basal breccia (site T15 near Barri) of the Cenozoic succession, but is never observed in the overlying formations (fig. 8). Outcrop-scale fractures are systematically found in the vicinity of major E-W trending normal faults of hectometric to kilometric-scale, which are sealed by the Oligocene Molasse Rouge [Haccard et al., 1989b]. These major faults crosscut earlier E-W trending folds, as observed in the Maurière anticline, and are sealed by the late Eocene 
to basal Oligocene basal breccia, except near Barri where the breccia is faulted. The extension therefore appears to be nearly coeval of the deposition of the basal breccia and to predate that of the Molasse Rouge: it is dated of the late Eocene-basal Oligocene. The normal faults, formed in already folded Mesozoic series (pre-Oligocene stage of folding), have subsequently been tilted during the post-Oligocene stage of folding. The amount of tilting of the fault systems cannot be directly obtained from the dip of Mesozoic strata and, consequently, backtilting of these fault systems to their initial position is not possible.

\subsection{Pre-late Eocene compression}

Several sets of conjugate faults with slickensides lying in the bedding plane have been measured in the upper Jurassic (Tithonian) and lower Cretaceous (Berriasian-Valanginian) series (fig. 9), in particular in the Clue de Barles (site M1A) and Clue du Pérouré (site K1A). After correction from the dip of the strata (back-tilting), these faults correspond to conjugate strike-slip faults indicating an average N-S direction of compression. The compression postdates the deposition of the lower Cretaceous strata and predates the first stage of folding sealed by the Oligocene deposits. These fault systems, which formed when the Mesozoic strata were still horizontal, subsequently underwent two stages of folding and should theoretically be restored to their initial position with two successive rotations. However, the fault systems back-tilted with a single rotation consistently provide a N-S direction of compression. This result indicates that the two successive rotations were nearly homo-axial and that the back-tilted fault systems are correctly restored to their initial position.

\subsection{Liassic extension}

In the Chine unit in the northern Barles half-window [Gidon and Pairis, 1992; fig. 1], normal faults, particularly conspicuous in the Hettangian strata, affect the overturned Liassic series (fig. 10). NW-SE trending faults are observed to the west of the Bès River in Pâturages 
de Chine, whereas NNE-SSW trending faults are observed to the east in Barres de Proussier. These faults are associated with thickness variations and even disappearance of the Domerian deposits in Barres de Proussier [Coadou et al., 1971], as described further west in the Clue du Vançon [Haccard et al., 1989b]. These faults are consequently interpreted as synsedimentary normal faults coeval with the deposition of the Liassic series. After back-tilting, these faults indicate a direction of extension striking NW-SE on average (between $\mathrm{N} 056^{\circ} \mathrm{W}$ and $\mathrm{N} 010^{\circ} \mathrm{E}$ ). These directions, however, are poorly constrained due to large uncertainties associated with the back-tilting of flat-lying, completely overturned strata. Once again, two successive rotations would be necessary to restore the fault sets to their initial position. In this case, the main uncertainty arises from the inaccuracy of strike measurement on almost horizontal planes (this strike being used as rotation axis for back-tilting).

\section{Discussion and conclusion}

\subsection{Reconciling micro-tectonic data with syn-depositional folding of the Vélodrome?}

The development of a foreland basin in front of the Digne nappe is marked by a sharp unconformity between Mesozoic and Cenozoic deposits, interpreted as a flexural forebulge unconformity [Elliot et al, 1985; Ford et al., 1999]. Sedimentary features in the DigneValensole basin, including asymmetric infill of the basin with important lateral thickness variations, migration of the molasses depocenter during the Miocene [Crumeyrolle et al., 1991], and sedimentary onlaps observed on the margins of the basin [Maillart et al., 1988; Haccard et al., 1989b], attest of a tectonically-controlled subsidence.

In addition, in the area of Barles, variations in strata dip in the marine molasse and the Valensole Conglomerates were taken as evidence for progressive unconformities in the north of the Vélodrome, near La Pousterle, and at the N-S closure of the Vélodrome fold to the east at Esclangon [fig. 3; Gigot et al., 1974; Haccard et al., 1989; Crumeyrolle et al., 1991; Gidon and Pairis, 1992]. The Vélodrome was subsequently considered as a growth fold developed 
during the deposition of the Miocene molasses ( 10-15 m.y.), before the southwestward thrusting of the Digne Nappe.

In the Vélodrome, however, the existence of these progressive unconformities is based on qualitative observations, like the panoramic view of the Vélodrome (fig. 11, top), with conflicting interpretations [inset in fig. 11; Haccard et al., 1989b; Gidon and Pairis, 1992]. On the aerial photographs draped on a digital elevation model at a $25 \mathrm{~m}$ resolution, sedimentary wedges expected for a growth fold with progressive unconformities are not visible (fig. 11, bottom; IGN-BRGM Géoportail; http://www.geoportail.fr/). In the field, the area of $L a$ Pousterle is characterized by poor exposures and the progressive unconformities could never be observed (B. Beaudoin, pers. comm., 2005). Furthermore, the progressive onlaps of the marine molasses on the Molasse Rouge described by Crumeyrolle et al. (1991) at Esclangon actually correspond to a tectonic contact between the Molasse Rouge tectonic slice of Aiguebelle (Gidon, 1989) (= tectonic slice of Esclangon [Haccard et al., 1989]) and the conglomeratic marine molasses of the Vélodrome. These remarks suggest that the existence of progressive unconformities in the Vélodrome is not firmly established at present.

Besides, in apparent conflict with the reports of syn-depositional deformation in the Vélodrome, our microstructural analysis in the Cenozoic molasses demonstrates that only two main fracturing stages are recorded in the Vélodrome:

(1) the first one occurred when the series were still horizontal, as shown by the completely back-tilted fault subset (see $\S 2.1$ ) yielding a coherent stress regime with a vertical $\sigma_{2}$ or $\sigma_{3}$ (within a $15-20^{\circ}$ error) in the entire molasse series (Figures 3 and 4);

(2) the second one postdated the entire folding of the molasses series (Figure 5).

These data suggest that the Vélodrome folding postdates the deposition of the Valensole Conglomerates and occurred in late Miocene-Pliocene times during the emplacement of the Digne Nappe. This result is consistent with the observations provided by reflection seismic profiles and exploration wells along the Durance fault near Manosque, in the western part of 
the Valensole basin. There, the marine to continental Miocene sediments rest unconformably upon the Pyrenean-Provençal compressional and Oligocene extensional structures, and were lately folded after their deposition during the late Miocene to Present [Roure and Coletta, 1996].

If syn-depositional deformation did prevail (resulting in unconformities such as between the marine molasses and the Valensole Conglomerates, as proposed by Haccard et al. [1989b]), not only contrasting amounts of tilting of the faults between the various formations would be needed to obtain a coherent stress regime, but a greater number of conjugate fault systems (requiring different tilting values) would also be expected in highly tilted formations (fig. 12).

Microtectonic data are therefore not in good agreement with the interpretation of the Vélodrome being a growth fold. In order to reconcile sedimentary patterns with microtectonic data, syn-depositional folding (and incremental tilting) of the foreland Vélodrome deposits must have been moderate at the most.

\subsection{Stress field evolution in relation with the geodynamic setting}

Figures 13, 14 and 15 provide a synthetic overview of the deformation in the Barles tectonic half-window since the Triassic. Four main phases of deformation testifying to the existence of major tectonic events have been recognized, from the youngest (4) to the oldest (1):

(4) a NNE direction of compression associated with south-verging folds may be attributed to the latest Alpine deformation phase related to the emplacement of the Digne Nappe. Noteworthily, the associated brittle deformation both predated (stage 4a) and postdated (stage 4b) the folding of the foreland series, but was only poorly recorded during folding. 
(3) a N-S extensional stage predating the Oligocene, marked by km-scale faults crosscutting earlier E-W folds. If one assumes that the folds formed during the pre-Priabonian Pyrenean-Provençal phase, the extensional event would have to be late Eocene in age and coincide with the formation of major rifts in Western Europe, from the Mediterranean area to Norway [e. g., Bergerat , 1987; Roure et al., 1992; Michon et al., 2003]. The N-S direction of extension documented in the area of Barles is very oblique to the E-W trending extension of the Western European Oligocene rift system, but is broadly consistent with the opening direction documented in the eastern Gulf of Lion [Réhault et al., 1984]. Assuming that the EW folds formed during the pre-Senonian phase of the Devoluy, the N-S extension may have occurred as soon as the late Cretaceous, as documented further west in the Ventoux-Lure area (Roure et al., 1992; Hibsch et al., 1992), and have later been reactivated during the late Eocene.

(2) a N-S compression accompanying the formation of E-W trending folds associated with the pre-Priabonian Pyrenean-Provençal deformation phase [Lemoine, 1972] or the pre-Senonian phase of folding of the Devoluy.

(1) an extension striking broadly NW-SE, coeval with the Liassic rifting of the Alpine Ocean [Lemoine et al., 1986; Roure et al., 1992].

A noticeable conclusion of this study is therefore that the major compressional phases are almost homo-axial in the Barles area. Interestingly, an additional, though poorly documented, post-Oligocene compressional phase striking WNW-ESE was also documented by three sets of conjugate strike-slip faults (fig. 13).

4.3 Evolution of the brittle deformation in response to the Alpine Mio-Pliocene deformation stage 
Three more-or-less continuous stages can be distinguished in the NNE-directed compressional stage associated with the latest Alpine deformation (stage 4 above; fig. 14 and $15)$ :

- after a period of sedimentation characterized by broadly conformable deposits in this part of the foreland basin, lasting from the Oligocene Molasse Rouge to the late Miocene Valensole Conglomerates, fracturing affected the entire series just before they were folded (stage 4a, fig. 15).

- These Tertiary series, together with the underlying formations, were then wrapped around $\mathrm{N} 90^{\circ}-120^{\circ} \mathrm{E}$ striking folds. Little brittle fracturing occurred during this stage, however. This could be tentatively related to the importance of bedding-parallel slip during folding.

- Brittle fracturing, mainly expressed as strike-slip faults, later resumed, apparently when the Digne Nappe overthrust the area (stage 4b). The emplacement of the Digne Nappe first triggered the deposition of the olistolitic Tanaron Formation, which is resting unconformably upon the already folded earlier Tertiary formations, and then sheared off earlier folds and anticlines. This final stage cannot, unfortunately, be dated accurately in the area but should be younger than approximately $6 \mathrm{Ma}$ (i.e., end of deposition of the Valensole Conglomerates).

Finally, it should be acknowledged that paleo-stress field reconstruction brings remarkably consistent results. In such a complicated tectonic setting, characterized by polyphase deformation and strong simple shear associated with the Digne Nappe emplacement, micro-structural analysis proves to be a powerful tool to decipher the evolution of the deformation, and perhaps help characterize deformation modes.

Acknowledgments. We are grateful to the Editor Michel Faure, and to François Roure and Jean-François Stephan for their constructive reviews of the manuscript. We thank Pascale 
Leturmy for fruitful discussions. We also thank Maurice Brunel for his stimulating remarks that motivated us to finalize this work. We thank all the students in Earth Sciences at the University Pierre and Marie Curie-Paris 6, with whom we collected micro-tectonic data during the Licence (third year) field-training course since 1996. Special thanks go to Roland Gouin, Emmanuelle Vigier, and Martin for their warm hospitality at the "Gîte des 3 Vallées", as well as to France and Joseph Amielh that received us the first years in their hotel in Barles. 


\section{References}

AGARD P. \& LEMOINE M. (2005). - Faces of the Alps: Structural and geodynamic evolution. Commission de la Carte Géologique du Monde, $48 \mathrm{p}$.

AGARD P., FOURNIER M. \& LACOMBE O. (2003). - Post-nappe extension in the inner Western Alps (Liguro-Piemontese Schistes Lustrés): continuity with late ductile exhumation. - Terra Nova, 15, 306-314, doi: 10.1046/j.1365-3121.2003.00498.x

ANDERSON E. M. (1951). - The Dynamics of Faulting. - 2nd ed., 206 pp, Oliver and Boyd, White Plains, N. Y.

ANGELIER J. (1984). - Tectonic analysis of fault slip data sets. - J. Geophys. Res., 89, 58355848.

ANGELIER J. (1990). - Inversion of field data in fault tectonics to obtain the regional stress, III, A new rapid direct inversion method by analytical means. - Geophys. J. Int., 103, 363376.

ARNAUD H., GIDON M. \& PAIRIS J.L. (1977). - Précisions sur la structure des chaînes subalpines méridionales dans la région de Faucon-Turriers-Clamensane (Alpes-de-HauteProvence). - Géologie alpine, 53, 5-34.

AUBOURG C., ROCHETTE P., STEPHAN J.-F., POPOFF M. \& CHABERT-PELLINE C. (1999). - The magnetic fabric of weakly deformed Late Jurassic shales from the southern subalpines chains (French Alps) and evidence for SW-directed tectonic transport direction. - Tectonophysics, 307, 15-31.

BAROUX E., BÉTHOUX N. \& BELLIER O. (2001). - Analyses of the stress field in southeastern France from eartquake focal mechanisms. - Geophys. J. Int., 145, 336-348.

BEAUDOIN B., CAVELIER C., HACCARD D., LANTEAUME M., \& PERRIN P. (1966). A propos de l'âge des molasses de Tanaron (Basses-Alpes). La redécouverte du gisement à Cérithes et ses consequences structurales. - Bull. Soc. géol. France, 8, 458-460.

BEAUDOIN B. \& GIGOT P. (1971). - Figures de courant et traces de pattes d'oiseaux associées dans la molasse miocène de Digne Basses Alpes (France). - Sedimentology, 17, 241-256.

BERGERAT F. (1987). - Stress fields in the European Platform at the time of Africa-Eurasia collision. - Tectonics, $\mathbf{6}, 99-132$.

CALAIS E., BAYER R., CHERY J., COTTON F., FlOUZAT M., JOUANNE F., MARTINOD J., MATHIEU F., SCOTTI O., TARDY M. \& VIGNY C. (2001). - REGAL: Réseau GPS permanent dans les Alpes, configuration et premiers résultats. - Bull. Soc. géol. France, 172, 141-158. 
CALAIS E., NOCQUET J.-M., JOUANNE F. \& TARDY M. (2002). - Current extension in the central part of the Western Alps from continuous GPS measurements, 1996-2001. Geology, 30, 651-654.

CLAUZON G., AGUILAR J.-P. \& MICHAUX J. (1989). - Relation temps - sédimentation dans le Néogène méditerranéen français. - Bull.Soc. géol. France, (8), V, 2, 361-372.

CLAUZON, G. (1975). - Sur l'âge villafranchien du chevauchement subalpin au droit de Puimoisson (Alpes-de-Haute-Provence). - C.R. Acad. Sci. Paris, 280, 2433-2436.

CLAUZON, G. (1979). - Le canyon messinien de la Durance (Provence, France) : une preuve paléogéographique du bassin profond de dessication. - Palaeogeography, Paleoclimatology, Palaeoecology, 29, 15-40.

CLAUZON, G., AGUILAR, J.P. \& MICHAUX J. (1987). - Mise en évidence d'un diachronisme de 5 M.a. au mur de la molasse miocène de Valensole (Alpes de Haute Provence, France). Révisions chronostratigraphiques et implications géodynamiques. C.R. Acad. Sci. Paris, 305, série II, 133-137.

COADOU A., BEAUDOIN B. \& MOUTERDE R. (1971). - Variations lithologiques et corrélations stratigraphiques dans le Lias moyen et supérieur de Barles et du plateau de Chine (Alpes de Haute-Provence). - Bull. Soc. géol. Fr., (7), XIII, 5-12.

COUEFFE R. \& MARIDET O. (2003) - Découverte de deux gisements à micromammifères du Burdigalien supérieur dans la Molasse Marine du bassin de Digne (Alpes-de-HauteProvence, SE France) - Implications stratigraphiques et tectoniques. - Eclogae Geologicae Helvetiae, 96, 197-207.

COUEFFE R., TESSIER B., GIGOT P. \& BEAUDOIN B. (2004). - Tidal rhythmites as possible indicators of very rapid subsidence in a foreland basin: an example from the Miocene Marine Molasse Formation of the Digne Foreland Basin, SE France. - J. Sedim. Res., 74, 746-759, DOI: 10.1306/040904740746.

CRUMEYROLLE P., RUBINO J.-L. \& CLAUZON G. (1991). - Miocene depositional sequences within a tectonally controlled transgressive-regressive cycle. - Spec. Publs. Int. Ass. Sediment., 12, 373-390.

CURNELLE R. \& DUBOIS P. (1986) - Évolution mésozoique des grands bassins français : bassin de Paris, d'Aquitaine et du Sud-Est. - Bull. Soc. géol. Fr., (8), II, 529-546.

DEBELMAS J. (1974). - Géologie de la France - Tome 2. Doin, Paris,p. 295-544.

DEBELMAS J. \& KERCKHOVE C. (1980). - Les Alpes franco-italiennes. - Géol. Alpine, 56, 21-58.

DEBELMAS J. \& LEMOINE M. (1970). - The western Alps: paleogeography and structure. Earth-Science Reviews, 6, 221-256. 
DUBAR M. (1984). - Chronologie et signification des dépôts continentaux du Néogène supérieur du basin de Riez - Valensole (Alpes-de-Haute-Provence, France). - Bull. Soc. géol. Fr., (7), XXVI, 971-978.

ELLIOTT T., APPS G., DAVIES H., EVANS M., GHIBAUDO G. \& GRAHAM R.H. (1985). - A structural and sedimentological traverse through the Tertiary foreland basin of the external Alps of South-East France. In: Allen, P., Homewood, P. \& Williams, G. (eds) International Symposium on Foreland Basins. International Association of Sedimentologists, Excursion guide book, Fribourg, 39-73.

FABBRI O. (2000). - Extensional deformation in the northern Ryukyu arc indicated by mesoscale fractures in the middle Miocene deposits of Tanegashima Island. - J. Geol. Soc. Japan, 106, 234-243.

FAUCHER T., GIDON M., PAIRIS J.L. \& MASCLE G. (1988). - Directions de transport au front de la nappe de Digne (chaînes subalpines méridionales). - C. R. Acad. Sc. Paris, 306, II, 227-230.

FLANDRIN J. (1966). - Sur l'âge des principaux traits structuraux du Diois et des Baronnies. - Bull. Soc. géol. Fr. (7) VIII, 376-386.

FORD M., LICKORISH W.H. \& KUSZNIR N.J. (1999). - Tertiary foreland sedimentation in the Southern Subalpine Chains, SE France: a geodynamic appraisal. - Basin Research, 11, 315-336.

FORD M., DUCHENE S., GASQUET D. \& VANDERHAEGHE O. (2006). - Two-phase orogenic convergence in the external and internal SW Alps. - J. Geol. Soc., 163, 815-826, DOI: $10.1144 / 0016-76492005-034$

FRY N. (1989). - Southwestward thrusting and tectonics of the western Alps. Geol. Soc. Spec. Publ., 45, 83-109.

GIDON M. \& PAIRIS J.L. (1986). - La nappe de Digne (Chaînes subalpines méridionales) : origine déplacement et signification régionale. - C. R. Acad. Sc. Paris, 303, II, 10, 981-984.

GIDON M. \& PAIRIS J.L. (1988). - La structure des environs de Digne (Chaînes subalpines méridionales, Alpes-de-Haute-Provence) : un exemple d'interférence entre l'avancée d'une nappe de charriage épiglyptique et la sédimentation sur son front. - C. R. Acad. Sc. Paris, 307, II, 1283-1288.

GIDON M. \& PAIRIS J.L. (1992). - Relations entre le charriage de la Nappe de Digne et la structure de son autochtone dans la vallée du Bès. - Eclogae geol. Helv., 85/2, 327-359.

GIDON M. (1975). - Sur l'allochtonie du Dôme de Remollon (Alpes françaises du Sud) et ses conséquences. - C.R.Acad.Sc. Paris, 280, 2829-2832. 
GIDON M. (1989). - La rupture des charnières anticlinales par cisaillement dans les flancs longs des plis : un mode méconnu de formation des chevauchements, observable dans les chaînes subalpines des Alpes occidentales françaises. - Géologie alpine, 65, 65-74.

GIGOT P. \& MEIN P. (1973). - Découvertes de mammifères aquitaniens dans la molasses burdigalienne du Golfe de Digne. - C.R.Acad.Sc. Paris, 276, 3293-3294.

GIGOT P., GRANDJACQUET C. \& HACCARD D. (1974). - Evolution tectonosédimentaire de la bordure septentrionale du bassin tertiaire de Digne depuis l'Eocène. - Bull. Soc. géol. Fr., (7), XVI, 128-139.

GOGUEL J. (1963). - L'interprétation de l'arc des Alpes occidentales. - Bull. Soc. géol. France,(7), V, 20-33.

GUBLER Y. (1959). - Etude critique des sources du matériel constituant certaines séries détritiques dans le Tertiaire des Alpes françaises du Sud : formation détritique de Barrême, Flysch, "Grès d'Annot". - Eclogae geol. Helv., 51, 942-977.

GUBLER Y., MALDIDIER C., MOUTERDE R. et al. (1961). - Lias dauphinois et Lias provençal. (in "colloque sur le Lias français"). - Mém. B.R.G.M., n4, 829-839.

HACCARD D., BEAUDOIN B., GIGOT P., JORDA M. et al. (1989a). - Carte géologique de la France (1/50 000), feuille LA JAVIE (918) - Orléans : Bureau de Recherche Géologique et Minière.

HACCARD D., BEAUDOIN B., GIGOT P. \& JORDA M. (1989b). - Notice explicative de la carte géologique de la France (1/50 000), feuille LA JAVIE (918) - Orléans : Bureau de Recherche Géologique et Minière. 152p.

HAUG E. (1891). - Les chaînes subalpines entre Gap et Digne. Contribution à l'histoire géologique des Alpes françaises. - Bull. Serv. Carte Géol. Fr., 21, III, p. 1-197.

HIBSCH C., KANDEL D., MONTENAT C. \& OTT D'ESTEVOU P. (1992) - Evènements tectoniques crétacés dans la partie méridionale du bassin subalpin (massif Ventoux-Lure et partie orientale de l'arc de Castellane, SE France); implications géodynamiques. l'Eocène. Bull. Soc. géol. Fr., (2), 163: 147-158

HIPPOLYTE J.C. \& DUMONT T. (2000). - Identification of Quaternary thrusts, folds and faults in a low seismicity area : examples in the Southern Alps (France). - Terra Nova, 12, $156-162$

JORDA M., COMBES P. \& PHILIP H. (1992). - Tectogenèse et morphogenèse quaternaries des chaînes subalpines méridionales (region de Digne et vallée de la Bléone). Quaternaire, 3, 129-135. 
JOUANNE F., HIPPOLYTE J.C., GAMOND J.F. \& MARTINOD J. (2001). - Current deformation of the Digne Nappe (southwestern Alps) from a comparison between triangulation and GPS data. - Geophys. J. Int., 144, 432-440.

KERCKHOVE C. (1969). - La zone du flysch dans les nappes de l'Embrunais-Ubaye (Alpes occidentales). - Géologie alpine, 45, 5-204.

KERCKHOVE C., GIDON M., MALARODA, R., BARFETY J.-C., BOGDANOFF S., LEMOINE M. et al. (1979). - Carte géologique de la France à 1 :250,000, feuille Gap (35). Orléans : Bureau de Recherche Géologique et Minière.

LABAUME P., RITZ J.F. \& PHILIP H. (1989). - Failles normales récentes dans les Alpes sud-occidentales : leurs relations avec la tectonique compressive. - C. R. Acad. Sc. Paris, 308 (II), 1553-1560.

LAPPARENT A-F. de (1938). - Etudes géologiques dans les régions provençales et alpines entre le Var et la Durance. Bull. Serv. Carte géol. de France, 198, XL, p. 1-305.

LEMOINE M. \& DE GRACIANSKY P.C. (1988). - Histoire d'une marge continentale passive : les Alpes occidentales au Mésozoïque. Introduction. - Bull. Soc. géol. Fr., (8), IV, 597-600.

LEMOINE M. (1972). - Rythme et modalités des plissements superposés dans les chaînes Subalpines Méridionales des Alpes Occidentales Françaises. - Geol. Runschau, 61, 3, 9751010.

LEMOINE M. (1973). - About gravity gliding tectonics in the Western Alps. Gravity and tectonics (De Jong and Scholten ed.) John Wiley \& Sons, New York, p. 201-216.

LEMOINE M., BAS T., ARNAUD-VANNEAU A., ARNAUD H., DUMONT T., GIDON M., BOURBON M., DE GRACIANSKY P.C., RUDKIEWICZ J.L., MEGARD-GALLI J., TRICART P. (1986). - The continental margin of the Mesozoic Tethys in the Western Alps. - Mar. Pet. Geol., 3, 179-199.

LICKORISH, W.H. \& FORD M. (1998). - Sequential restoration of the Southern Subalpine Chain, SE France: implications for late Alpine tectonics. - In: Cenozoic foreland basins of western Europe, Mascle, A., Puigdefàbregas, C., Luterbacher, H.P. \& Fernandez, M. (eds), Geol. Soc. Spec. Publ., 134, 189-211.

MADDEDU B., BETHOUX N. \& STEPHAN J.F. (1996). - Déformations et champs de contraintes récents à actuel dans les Alpes sud-occidentales: approche sismotectonique. Bull. Soc. géol. Fr., 167, 797-810.

MAILlART J., BEAUDOIN B., COJAN I., JOSEPH P. \& PINOTEAU B. (1988). Déformation synsédimentaire ou compaction différentielle, exemples dans le sud-est de la France. - Notes et Mémoires, Total C.F.P., G.S. Genebass, 21, pp 249-257. 
MERLE O. \& BRUN J.P. (1984). - The curved translation path of the Parpaillon nappe (French Alps). - J. Struct. Geol., 6, 711-719.

MICHON L., VAN BALEN R.T., MERLE O. \& PAGNIER H. (2003). - The Cenozoic evolution of the Roer Valley rift system integrated at a European scale. - Tectonophysics, 367, 101-126.

MOUTERDE R. (1961). - Variations du Lias supérieur entre Gap Digne et Castellane. (in "colloque sur le Lias français"). - Mém. B.R.G.M., 4, 715-718.

MOUTERDE R., KERRIEN Y., LABOURGUIGNE J. \& MANIVIT J. (1971). - Le Lias et le Bajocien de La Javie (Basses-Alpes). - Bull. Soc. géol. Fr., (7), VIII, 347-352.

ONASCH C. M. (1983). - Dynamic analysis of rough cleavage in the Martisburg Formation, Maryland. - J. Struct. Geol., 5, 73-82.

REBAÏ S., PHILIP H. \& TABOADA A. (1992). - Modern tectonic stress field in the Mediterranean region : evidence for stress deviation at different scales. - Geophys. J. Int., 110, 106-140.

REHAULT J.-P., BOILlOT G. \& MAUFFRET A. (1984). - The western Mediterranean basin geological evolution. - Mar. Geol., 55, 447-477.

RITZ J.F. (1992). - Tectonique récente et sismotectonique des Alpes du Sud, analyse en termes de contraintes. - Quaternaire, 3, 111-124.

ROURE F. \& COLETTA B. (1996). - Cenozoic inversion structures in the foreland of the Pyrenees and Alps. In: Ziegler, P.A., Horvath, F. (Eds.), Peri-Tethys Memoir 2: Structure and Prospects of Alpine Basins and Forelands. Mém. Mus. Natn. Hist. Nat., vol. 170, pp. 173-209.

ROURE F., BRUN J.P., COLETTA B. \& VAN DEN DRIESSCHE J. (1992). - Geometry and kinematics of extensional structures in the Alpine foreland of southeastern France. - $J$. Struct. Geol., 14, 503-519.

SIDDANS A.W. B. (1979). - Arcuate folds and thrust patterns in the Subalpine Chains of Southeast France. - J. Struct. Geol., 1, 117-126.

SINCLAIR H.D. \& ALLEN P.A. (1992). - Vertical versus horizontal motions in the Alpine orogenic wedge: stratigraphic response in the foreland basin. - Basin Research, 4, 215-232.

SISSINGH W. (2001). - Tectonostratigraphy of the West Alpine Foreland: correlation of Tertiary sedimentary sequences, changes in eustatic sea-level and stress regimes. Tectonophysics, 333, 361-400.

SUE C., THOUVENOT F., FRECHET J. \& TRICART P. (1999) - Widespread extension in the core of the Western Alps revealed by earthquake analysis. - J. Geophys Res., 104, $25,611-25,622$. 
TRICART P., SCHWARTZ S., SUE C., POUPEAU G. \& LARDEAUX J.M. (2001). La dénudation tectonique de la zone ultradauphinoise et l'inversion du front briançonnais au sud-est du Pelvoux (Alpes occidentales) : une dynamique miocène à actuelle. - Bull. Soc. géol. Fr., 172, 49-58.

TRICART P. (1984). - From passive margin to continental collision: a tectonic scenario for the Western Alps. - American J. Sci., 284, 97-120.

TRICART P. (1986). - Le chevauchement de la zone briançonnaise au Sud-Est du Pelvoux : clé des rapports zone externe-zones internes dans les Alpes occidentales. - Bull. Soc. géol. Fr., 2, 233-244.

VANDYCKE S. \& BERGERAT F. (2001). - Brittle tectonic structures and paleostress analysis in the Isle of Wight, Wessex basin southern UK. - J. Struct. Geol., 23, 393-406.

YAMAJI A., TOMITA S., \& OTSUBO M. (2005). - Bedding tilt test for paleostress analysis. - J. Struct. Geol., 27, 161-170. 


\section{Figure captions}

Figure 1. a. Structural map of external zone of the southwestern Alps with location of the study area [after Agard and Lemoine, 2005]. Bold arrows indicate the transport direction of the Digne Nappe. b. Geological map of the front of the Digne Nappe in the area of Barles and Valensole basin [after the 1:250,000 geological map of Gap; Kerkhove et al., 1979]. c. Synthetic cross-section of the Barles tectonic half-window located in figure $1 \mathrm{~b}$.

Figure 2. Stratigraphic synthesis of the sedimentary succession exposed in the Barles tectonic half-window.

Figure 3. Compressional stress field recorded in the Upper Eocene to Upper Miocene molassic formations of the Valensole Basin in the Vélodrome area. Several systems of conjugate faults documented scattered principal stress directions (black overlay). After backtilting (i.e., correction from the tilt of the strata, Table 1), two sets of conjugate reverse (top) and strike-slip (bottom) faults are obtained (white overlay; back-tilting angle near stereonet), consistently indicating a NNE-SSW direction of compression. Stereonets show fault slip data in equal-area lower hemisphere projection and arrows indicate the trend of the horizontal principal stresses computed from fracture analysis. Stars in stereonets correspond to the principal stress axes: $\sigma_{1}$ (five branches), $\sigma_{2}$ (four branches), and $\sigma_{3}$ (three branches). Dashed line is for the bedding plane. Geological map after the geological map of La Javie, 1:50,000 [Haccard et al., 1989a]. The ages of the youngest formations have been revised according to Clauzon et al. [1987, 1989]. t-1, Trias-Lias. j-n, Jurassic (Dogger and Malm)-Neocomian. e7$\mathrm{gBr}$, late Eocene-basal Oligocene basal breccia of the Molasse Rouge; g1-2R, Oligocene Molasse Rouge; g1-2G and m1, Oligocene grey lacustrine molasses and Aquitanian molasse of Lambert ; m1-2, Aquitanian-Burdigalian conglomeratic marine molasse; m2, Burdigalian 
silty-sandy marine molasse; m3-5, Langhian-Early Serravalian molasses with Cerithes; m5-p, Serravalian-Tortonian Valensole Conglomerates; p, late Miocene olistolitic Tanaron Formation.

Figure 4. NE-SW cross-section of the Vélodrome (located in fig. 3) with stereonets projected in the section plane. Fault systems measured in the field (black overlay) provide inconsistent principal stress directions. The same fault systems after back-tilting (white overlay; backtilting angle near stereonet) consistently provide a direction of compression $\left(\sigma_{1}\right)$ between N-S and NE-SW. Tith, Tithonian; Ber, Berriasian. Same legend as Figure 3.

Figure 5. Post-folding NNE-SSW compressional stress field recorded in the Triassic to Miocene formations of the Barles tectonic half-window. h5, Stephanian. $t$, Trias. $1_{n}$, thick Lias of the Digne Nappe. $1_{c}$, thin Lias of the autochtonous (Chine unit). j1, Bajocian. j2-4, Bathonian, Callovian, Early Oxfordian (Terres Noires). j5-9, Late Oxfordian, Kimmeridgian, Tithonian. n1, Berriasian. n2-6, Valanginian-Albian. e7-gBr, late Eocene-basal Oligocene basal breccia of the Molasse Rouge; g1-2R, Oligocene Molasse Rouge; g1-2G and m1, Oligocene grey lacustrine molasses and Aquitanian molasse of Lambert ; m1-2, AquitanianBurdigalian conglomeratic marine molasse; m2, Burdigalian silty-sandy marine molasse; m35, Langhian-Early Serravalian molasses with Cerithes; m5-p, Serravalian-Tortonian Valensole Conglomerates; p, late Miocene olistolitic Tanaron Formation. q, Quaternary formations.

Figure 6. Synfolding compressional faulting in the Conglomeratic Molasse at site T31., Complete back-tilting of $140^{\circ}$ yields an inconsistent stress solution (with sub-vertical faults bearing nearly dip-slip striations), whereas partial back-tilting of $70^{\circ}$ of the fault system yields a system of conjugate reverse faults (T31**) with $\sigma_{1}$ striking NNE-SSW. 
Figure 7. WNW-ESE fold (axes computed by cylindrical best fit; Table 2) in the Liassic to Miocene succession. Open arrows indicate the direction of shortening perpendicular to fold axes. Same legend as Figure 5.

Figure 8. N-S extensional stress field recorded in the Mesozoic series and the late Eocene basal breccia (near Barri) in the vicinity of major normal faults sealed by the Oligocene Molasse Rouge. Same legend as Figure 5.

Figure 9. Pre-late Eocene N-S compressional stress field recorded in the Mesozoic formations of the Barles tectonic half-window. Conjugate strike-slip fault systems measured in the field (black overlay) yield, after back-tilting (white overlay), a N-S direction of compression. Same legend as Figure 5.

Figure 10. NW-SE extensional stress field recorded in the Liassic formations of the Barles tectonic half-window. Conjugate normal fault systems measured in the field (black overlay) yield, after back-tilting (white overlay), a poorly constrained NW-SE direction of extension. The uncertainty on stress directions arise from the inaccuracy of strike measurement of flatlying, completely overturned strata. Same legend as Figure 5.

Figure 11. Top: panoramic view of the Vélodrome from Esclangon $(1151 \mathrm{~m}$; i. e. from the east), redrawn after Haccard et al. [1989b; their figure 16]. Insets show three geometrical configurations of the molasses deposits near La Pousterle: (a) the Valensole Conglomerates are resting on the conglomeratic marine molasses through a sharp unconformity $\left(90^{\circ}\right)$, after Haccard et al. [1989b; their figure 14]. (b) Progressive onlap and tilting of the Valensole Conglomerates are suggested by Gidon and Pairis [1992; their figure 6]. (c) The conformable molasse deposits are folded after the deposition of the Valensole Conglomerates (m5-p). 
Bottom: 3D view of the Vélodrome (aerial photographs and $25 \mathrm{~m}$ digital elevation model of IGN-BRGM Géoportail; http://www.geoportail.fr/) and interpretative draft with bedding traces in the molasse formations. The area of La Pousterle-Coustagne is characterized by poor exposures due to dense plant cover. Converging depositional surfaces (sedimentary wedges) expected for a growth fold with progressive unconformities are not observed in the aerial view.

Figure 12. Two hypotheses of syn- or post-depositional folding with stress field recording during folding.

Figure 13. Synthesis of Mesozoic and Cenozoic brittle deformation in the Barles tectonic half-window. Four main stages of deformation are identified: (1) a Liassic NW-SE extension, (2) a late Cretaceous-Eocene Pyrenean-Provençal N-S compression immediately followed by (3) a late Eocene-early Oligocene N-S extension, and (4) a NNE-SSW compression of Miocene-Pliocene age. Arrows indicate the trend of inferred horizontal principal stresses computed (solid arrows) or inferred (open arrows).

Figure 14. Evolution of the deformation in the area of Barles since the Lias. Arrows indicate the trend of inferred horizontal principal stresses computed (solid arrows) or inferred (open arrows). Same legend as Figure $1 b$.

Figure 15. Four stages evolution of the Cenozoic deformation in the Barles area: (a) unfolded Oligocene unconformity (posterior to the first stage of folding and to the late Eocene extension stage); (b) end of deposition of the molasse sequences in the foreland basin (including Valensole Conglomerates); (c) first stage of brittle deformation with layer-parallel shortening (stage 4a) in the molasse series and inception of the emplacement of the Digne 
Nappe; (d) final stage of brittle deformation after the Vélodrome folding and during the emplacement of the Digne Nappe. 


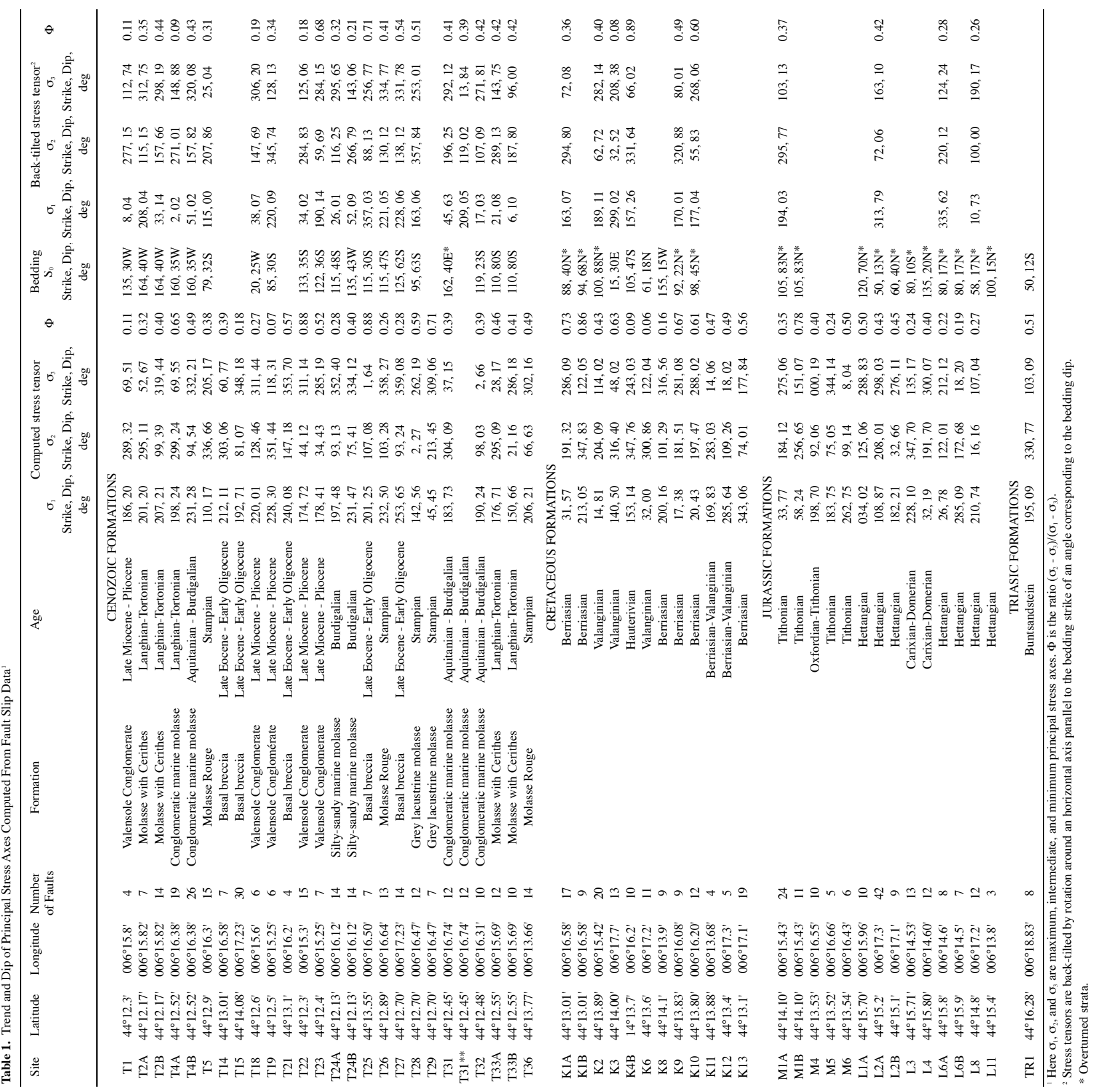


Table 2. Stike and Dip of Fold Axes Computed From Bedding Planes

\begin{tabular}{ccccccc}
\hline Site & Latitude & $\begin{array}{c}\text { Longitude } \\
\text { of }\end{array}$ & $\begin{array}{c}\text { Number } \\
\text { Bedding } \\
\text { Planes }\end{array}$ & Formation & Age & Fold axis $^{1}$ \\
& & & & & & $\begin{array}{c}\text { Strike, Dip, } \\
\text { deg }\end{array}$ \\
\hline T8 & $44^{\circ} 12.8^{\prime}$ & $006^{\circ} 16.5^{\prime}$ & 18 & Molasse Rouge & Stampian & 122,32 \\
T9 & $44^{\circ} 12.7^{\prime}$ & $006^{\circ} 17.1^{\prime}$ & 17 & Molasse Rouge & Stampian & 118,34 \\
T12 & $44^{\circ} 12.5^{\prime}$ & $006^{\circ} 15.7^{\prime}$ & 20 & Valensole Conglomerate Late Miocene - Pliocene & 287,25 \\
T13 & $44^{\circ} 13.7^{\prime}$ & $006^{\circ} 15.1^{\prime}$ & 39 & Molasse Rouge & Stampian & 291,08 \\
T20 & $44^{\circ} 12.7^{\prime}$ & $006^{\circ} 16.6^{\prime}$ & 23 & Molasse Rouge & Stampian & 146,35 \\
T35 & $44^{\circ} 13.88^{\prime}$ & $006^{\circ} 13.68^{\prime}$ & 19 & Molasse Rouge & Stampian & 106,41 \\
K4A & $44^{\circ} 13.6^{\prime}$ & $006^{\circ} 16.4^{\prime}$ & 12 & & Hauterivian & 294,18 \\
K5 & & & 17 & & Valanginian & 303,25 \\
L7 & & & 22 & & Lias-Dogger & 106,00 \\
L10 & $44^{\circ} 15.4^{\prime}$ & $006^{\circ} 13.8^{\prime}$ & 18 & & Hettangian & 286,05 \\
\hline
\end{tabular}

${ }^{1}$ Cylindrical best fit 


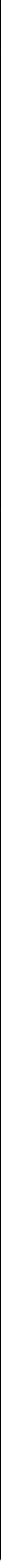

\begin{tabular}{|c|c|c|c|}
\hline Toarcian - Aalenian 17 & 171.6 & \multirow{2}{*}{$\begin{array}{l}=== \pm==\text { Thard ground_- } \\
\text { reddish limestones with crinoids } \\
\text { and marls }\end{array}$} & \multirow{3}{*}{$\begin{array}{l}\text { DETAILS } \\
\text { OF THE } \\
\text { LIASSIC } \\
\text { SEQUENCE }\end{array}$} \\
\hline Domerian & & & \\
\hline Carixian & & \begin{tabular}{|l|l|l|l|l} 
& & & & \\
\end{tabular} & \\
\hline Lotharingian & & dark layered limestones & \\
\hline Sinemurian & & sinuous limestones and marls & \\
\hline Hettangian & 196.5 & 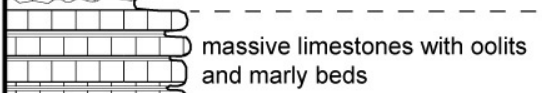 & $\mathrm{m}$ \\
\hline
\end{tabular}




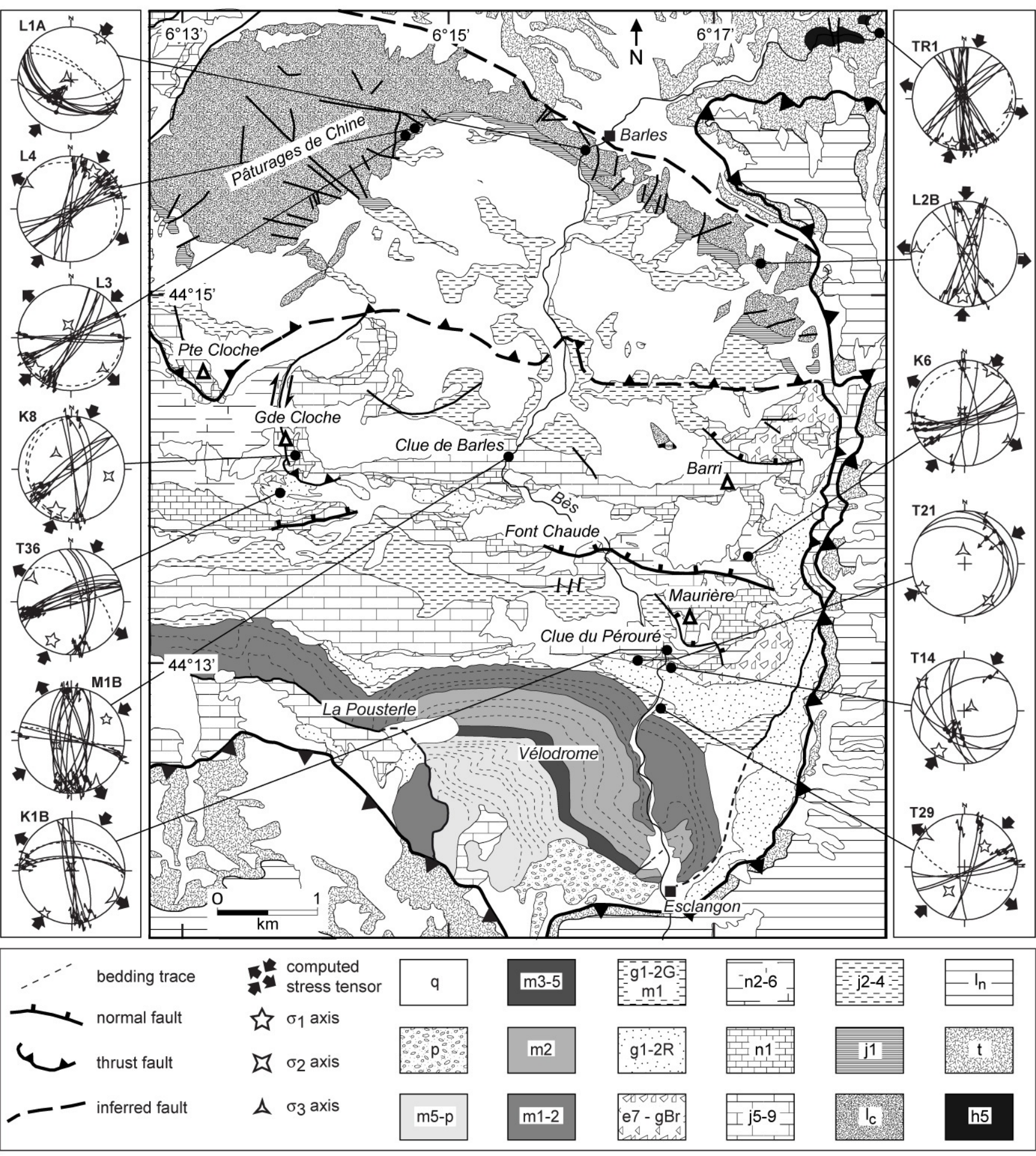

Figure 5 


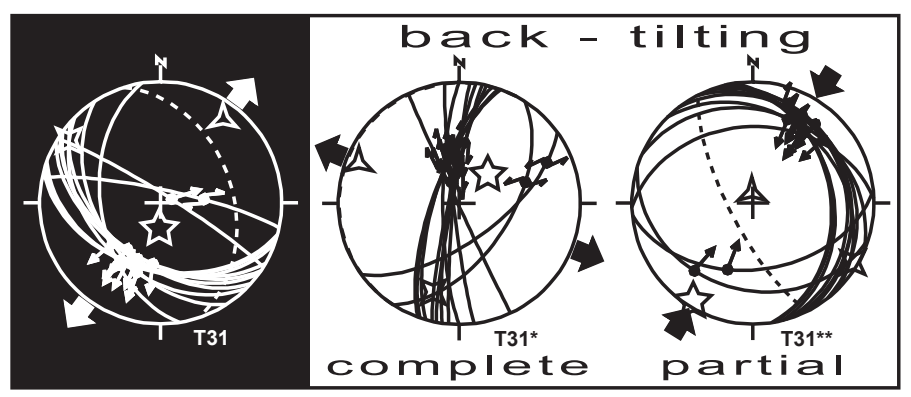

Figure 6 


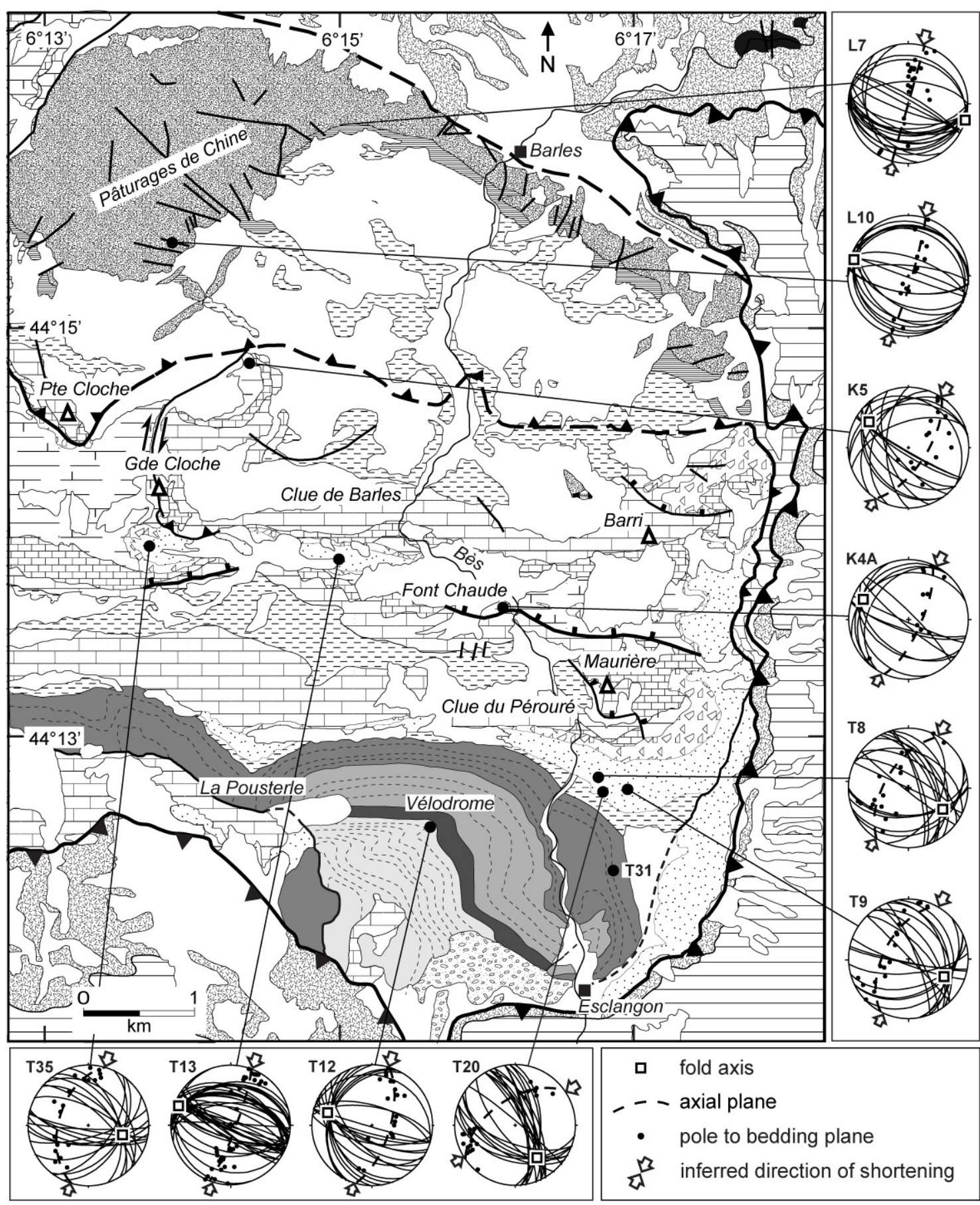




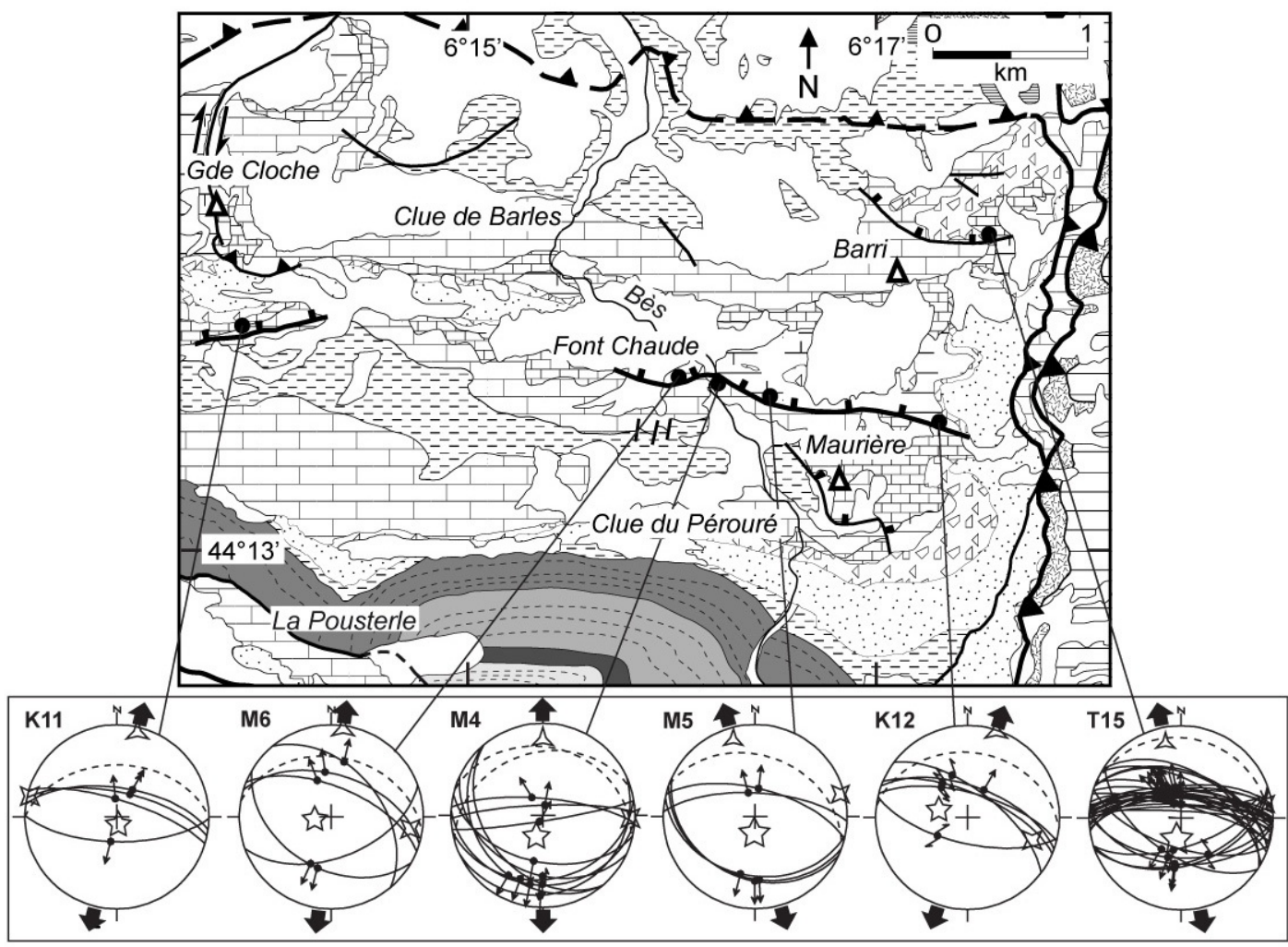

Figure 8 

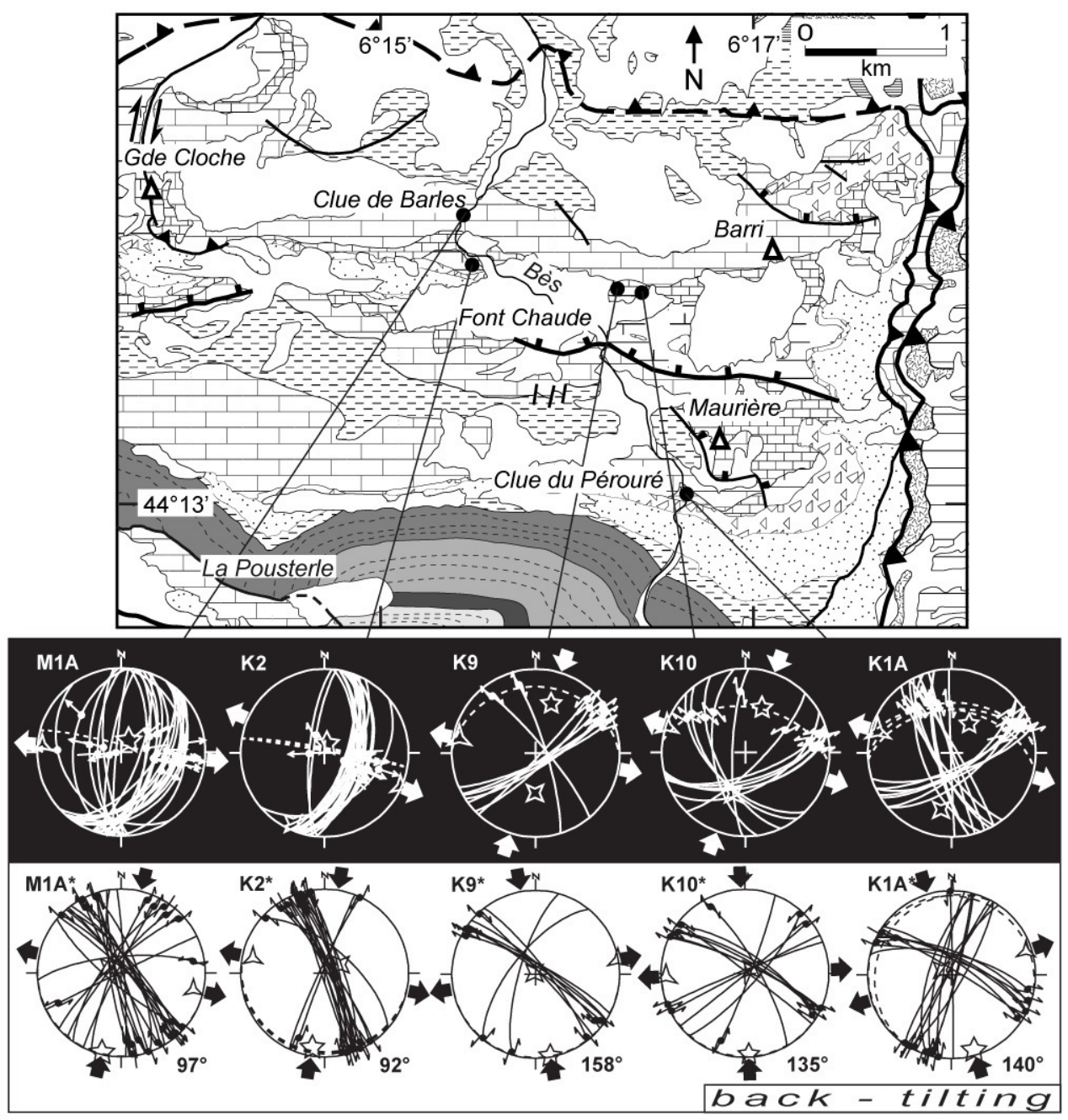

Figure 9 


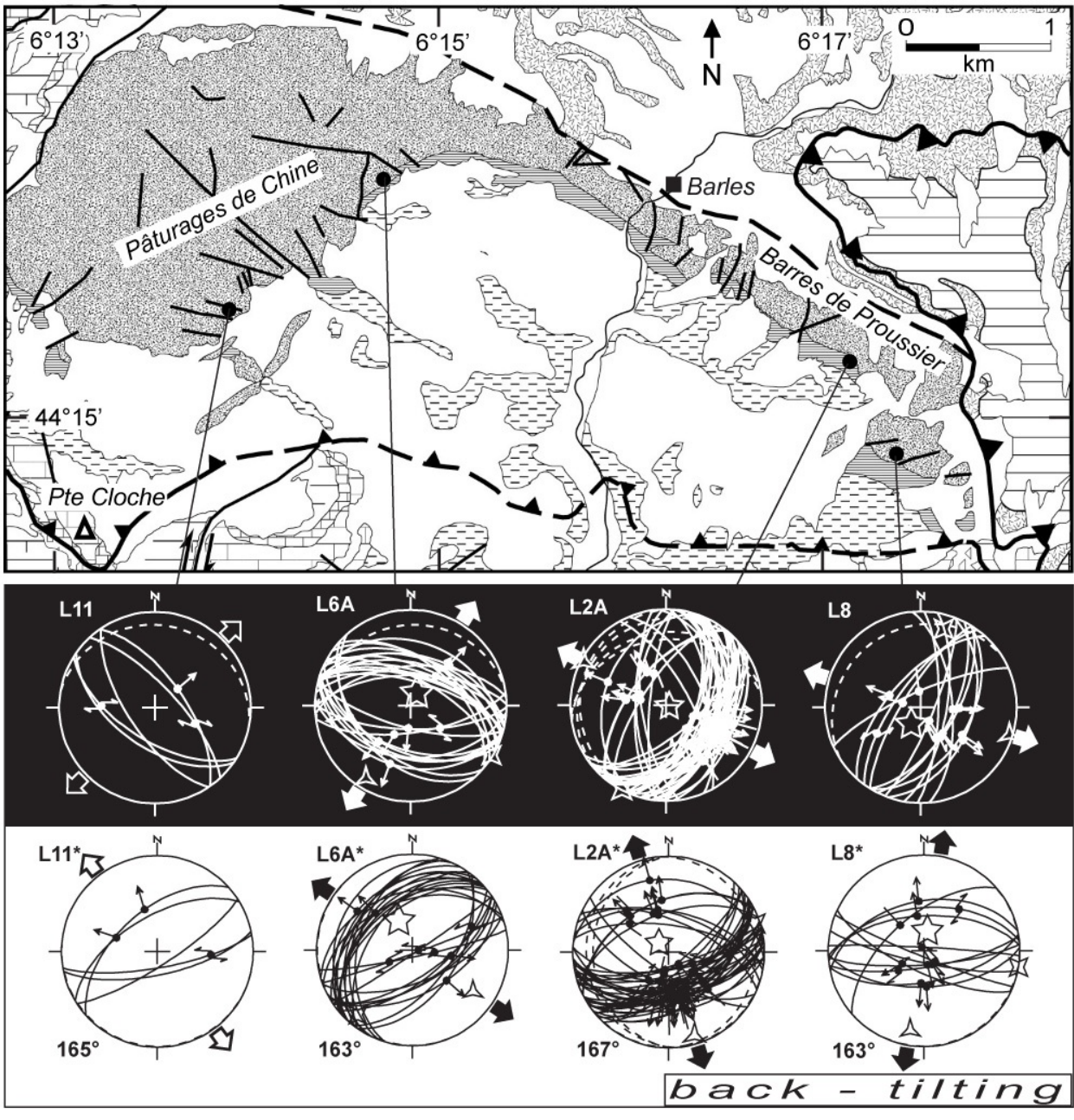

Figure 10 


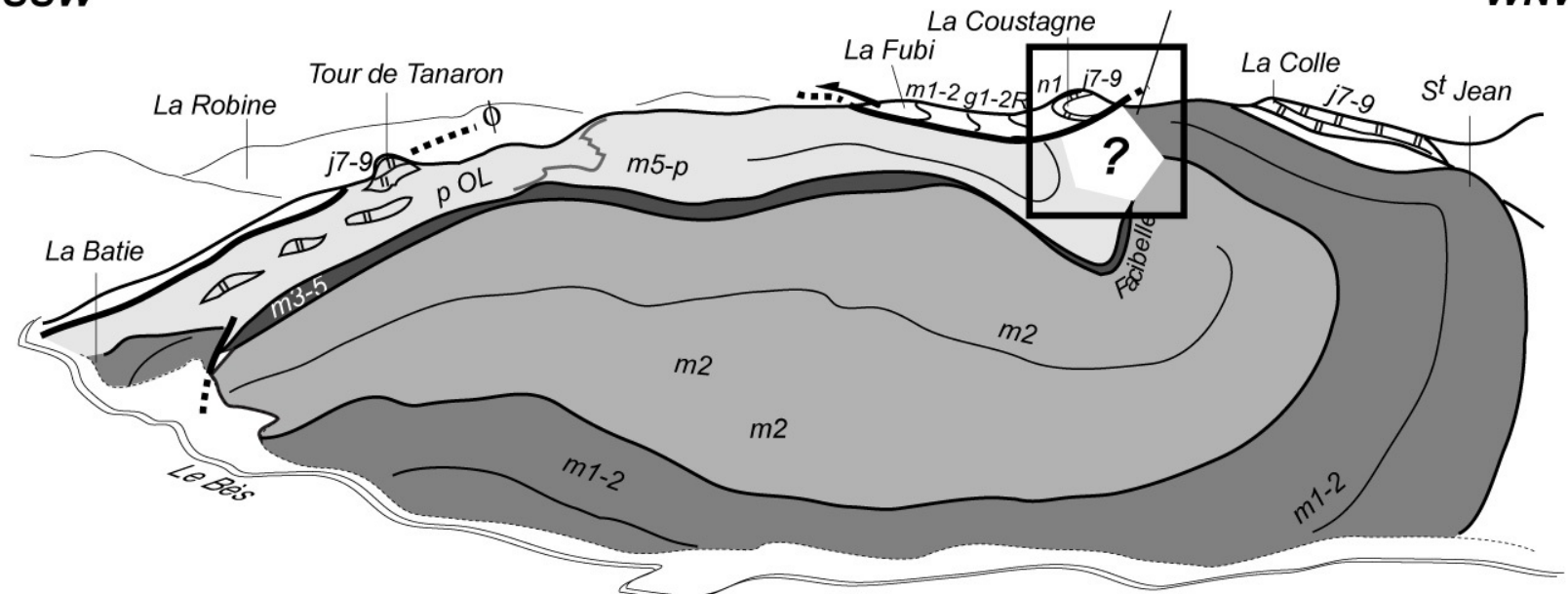

\begin{tabular}{|c|c|}
\hline$m 5-p$ & Valensole Conglomerates \\
\hline$m 3-5$ & Molasse with Cerithes \\
\hline$m 2$ & Silty-sandy marine molasse \\
\hline$m 1-2$ & Conglomeratic marine molasse \\
\hline$g 1-2 R$ & Molasse Rouge \\
\hline$n 1$ & Berriasian \\
\hline j7-9 & Tithonian massive limestone \\
\hline
\end{tabular}
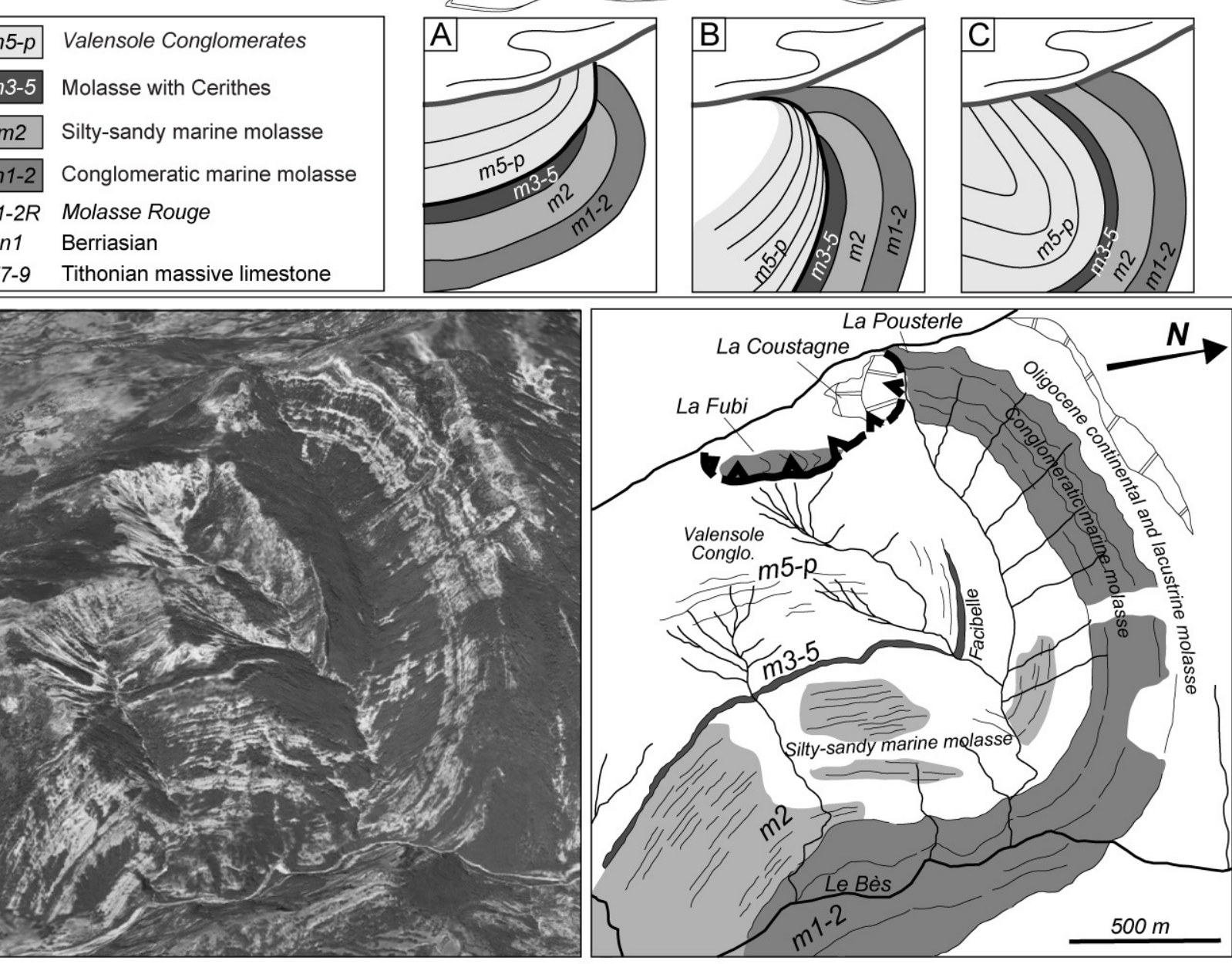

Figure 11 


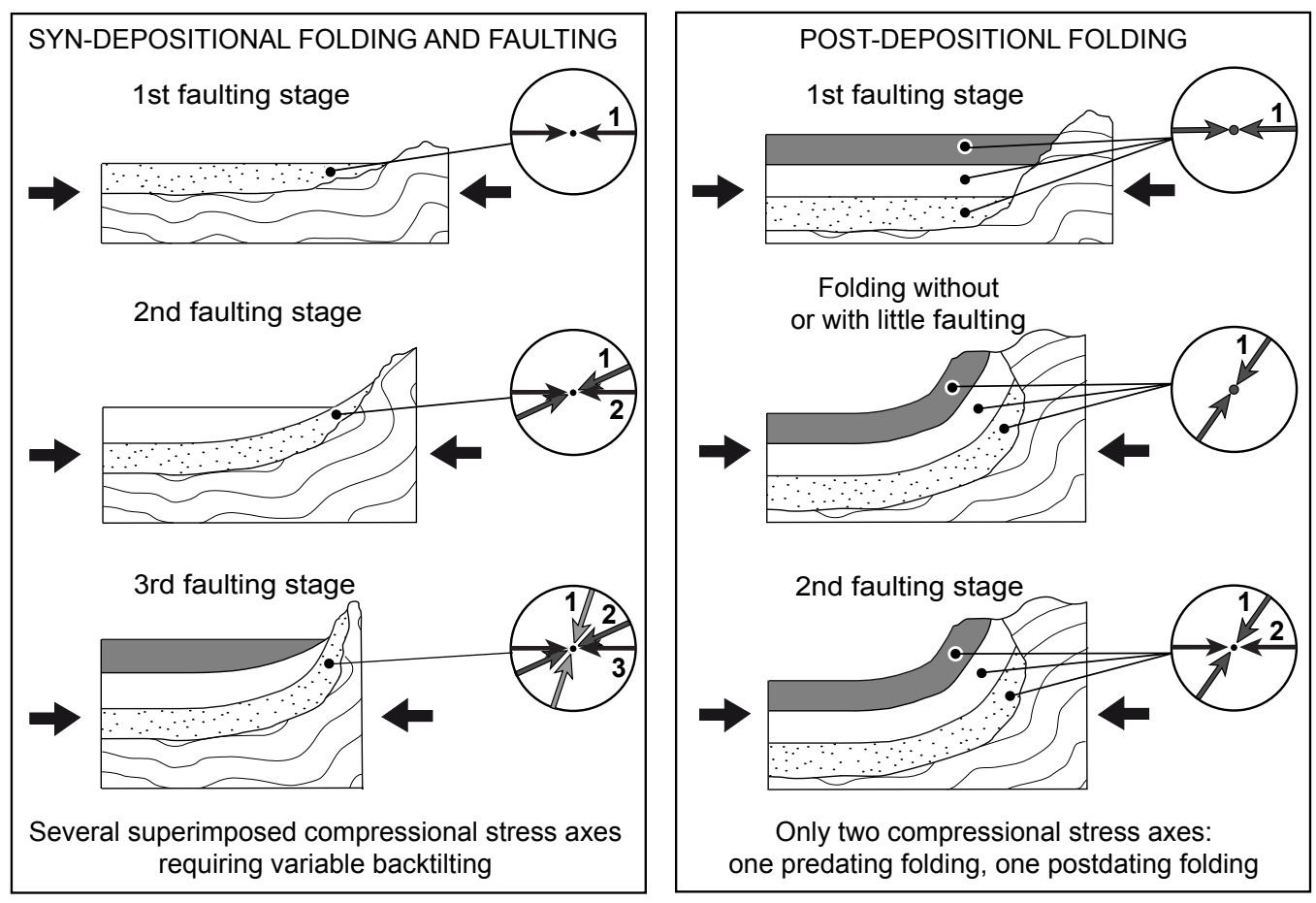

Figure 12 


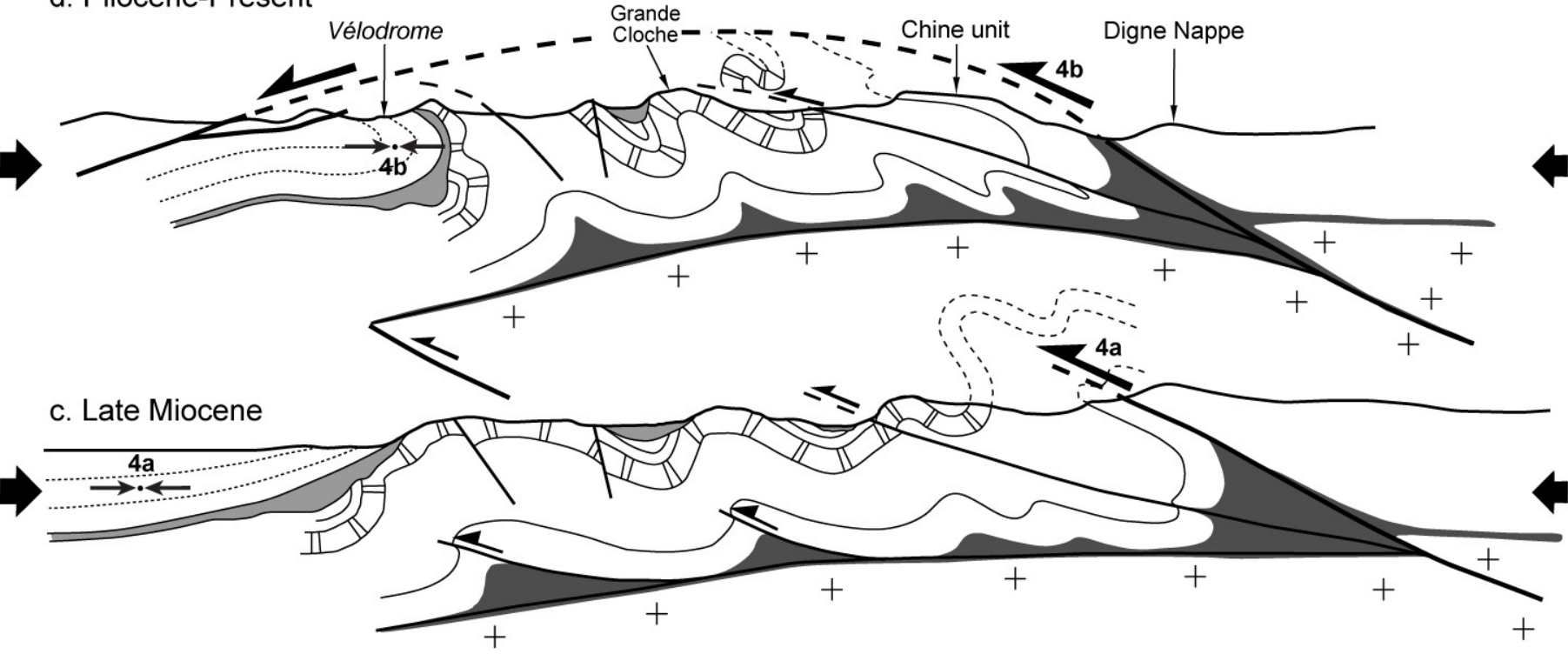

b. End of Middle Miocene
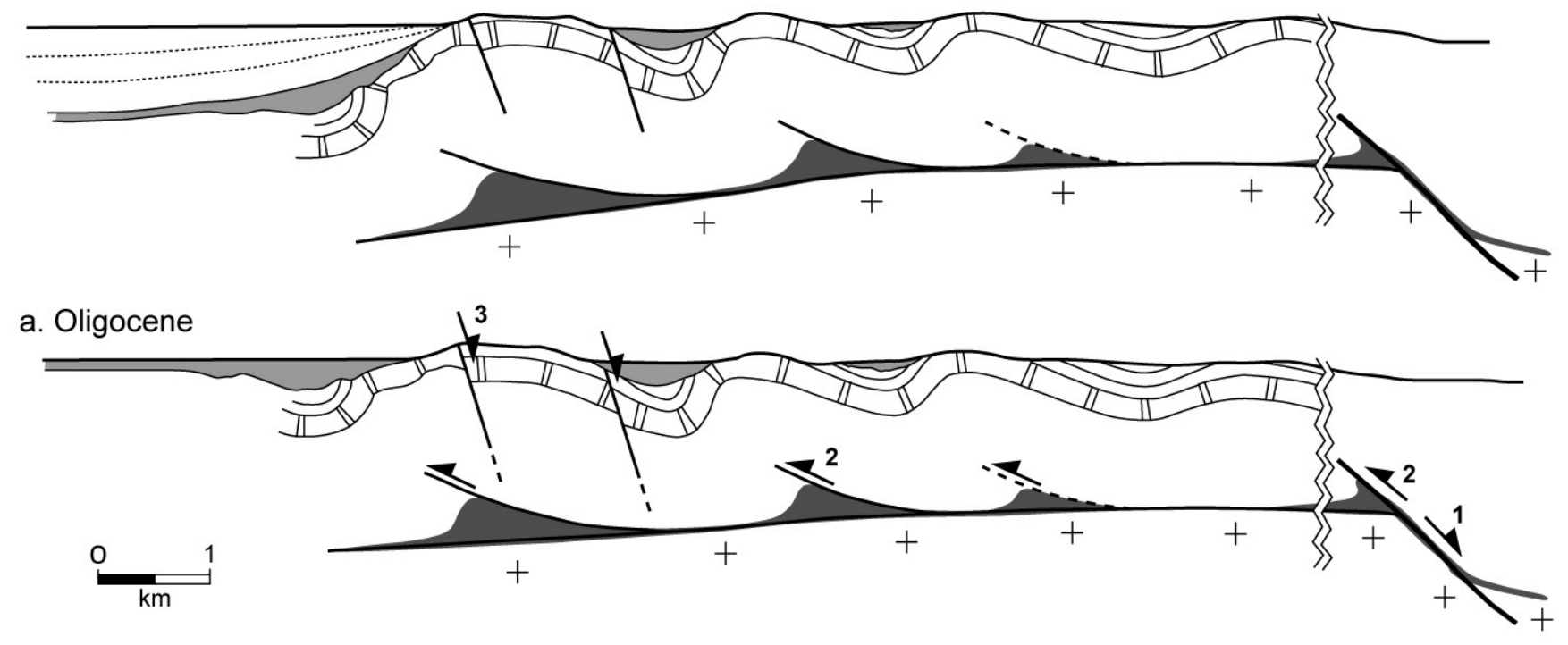

Figure 15 